Кристина Р. Митић ${ }^{1}$

Универзитет у Нишу

Филозофски факултет

Департман за србистику ${ }^{2}$
УДК: 821.163.41.09 Karadžić V. S.

ДОИ: https://doi.org/10.46630/gsrj.18.2020.03

\title{
КОВЧЕЖИЋ ВУКОВИХ ИДЕЈА
}

„За отаџбину се може гинути на сваком послу.”

Даничић

У раду ће бити предочен пут Ковчежића за историју, језик и обичаје Срба сва три закона до нас и наших дана. Биће узета у обзир неколика издања овог дела, као и критички написи досадашњих истраживача Ковчежића. Њихови напори уродили су плодом да дело не остане у сенци и да идеје Вука Стефановића Караџића буду сачуване и представљене.

Кључне речи: Караџић, Ковчежић, издања, садржај, идеје.

\section{Издања Ковчежића}

После 1847. године, која се рачуна годином незваничне Вукове победе, још три потпуно нова дела објављује Караџић, а то су: Ковчежсћ за историју, језик и обичаје Срба сва три закона, 1849. године, Примери српскословенског језика, 1857. године и Правитељствујушчи совјет сербски за времена КараЂорђијева или отимање ондашњијех великаша око власти, 1860. године.

Ковчежић је објављен, дакле, у повечерје Бечког књижевног договора. Дело је штампано у јерменском манастиру у Бечу, на 128 страна основног текста и још 26 страна које обухватају имена претплатника. У то време може се већ увелико говорити о Вуковој „пренумерантској традицији”, његовом виђењу снаге у претплатницима, као и довијању да обезбеди средства за штампу. Он тако бележи кад пише о пренумерантима за Ковчежић да многи, заправо, нису пренумеранти за ту публикацију него за Пословице, али да се он нада да ће и Ковчежић радо узети. Вукови пренумеранти за ову књигу били су из Берлина, Беча, Биограда у Србији, и то „од искушеника до војни-

\footnotetext{
${ }^{1}$ kristina.mitic@filfak.ni.ac.rs

${ }^{2}$ Рад је усмено изложен на трибини Нишког културног центра 24. 4. 2019. године поводом јубилеја 170 година од изласка Вуковог дела Ковчежић за историју, језик и обичаје Срба сва три закона. Писан је и представља се у оквирима рада на интерном пројекту Филозофског факултета Универзитета у Нишу: Истраживање књижевне прошлости и садашњости на простору југоисточне Србије, бр. 183/1-16-01, чији је руководилац проф. др Горан Максимовић.
} 
ка", како стоји у списку, из Водица, Вуковара, Граца, Дубровника, Земуна, златног Прага, Карловца, Карловаца, Котора, Крагујевца, Крушевца, Ливна, Лознице, Макарске, Мостара, Херцег Новог, Обровца, Осијека, Петрограда, Петриње, Пеште, Плашког, Плоча, Хрватске Подравине, Пожаревца, Руме, Ријеке, Сења, Сплита, Стоца, Темишвара, Трста, Целовца, Чачка, Шибеника, Шида, Брода, Задра, Цетиња (ЕТНОГРАФСКИ СПИСИ 1972: 118-140).

Етнолог и етнограф Миленко С. Филиповић приредио је 1972. године Етнографске списе, међу којима су написи о Милошу Обилићу, о појму кмет, Ковчежић за историју, језик и обичаје Срба сва три закона, као и Вуково дело из рукописне заоставштине Живот и обичаји народа српскога. Ови „етнографски списи” део су критичког Просветиног издања Вукових Сабраних дела поводом стогодишњице Вукове смрти. Филиповићеви главни помагачи у овом послу били су историчари књижевности Мирослав Пантић и Голуб Добрашиновић. Критички напис одговорног приређивача носи наслов Вук Караиић и српска етнологија. ${ }^{3}$

У години јубилеја - двеста година Вукове „канонске” Пјеснарице, а 165 година од Вуковог објављивања етнографског и етнолошког списа Ковчежић, појавило се његово фототипско издање, приређено у издању Вукове задужбине и уз поговор историчара књижевности, академика Наде Милошевић Ђорђевић, која највише пише о Вуковом уводном чланку Срби сви и свуда; историчар књижевности Душан Иванић исте, 2014. године, свом избору Вукових чланака, полемика, критика и предговора у издању Андрићевог института даје наслов Срби сви и свуда: о књижевности и јези$\kappa y$, и о Ковчежићу пише: „Вук њиме обиљежава или тематизује цјелокупно своје дјело: познати / описати српски народ гдје се год налази, полазећи од језика као исконског чиниоца рода" (ИВАНИЋ 2014: 15) у предговору под насловом Вук о српском језику и књижевности или Срби сви и свуда. ${ }^{4}$

Вуковом књигом Ковчежић бавили су се бројни и различити истраживачи, а за сачињавање овог осврта после 170 година драгоцени, и незаобилазни, и пре свих, били су написи Љубомира Стојановића, Миленка С. Филиповића, Миодрага Поповића, Миљане Радовановић, Владимира Стојанчевића, Миодрага Матицког, Наде Милошевић-Ђорђевић, Душана Иванића, Бошка Сувајџића.

\footnotetext{
${ }^{3}$ Наредне 1973. године етнограф Миљана Радовановић пише монографију Вук Каращић, етнограф и фолклорист у угледној серијској публикацији Српски етнографски зборник. Сагледавајући укупни Вуков етнографски рад, она Ковчежићу даје централно место у овој монографији и придружује се претходећим размишљањима Александра Белића, Татомира Вукановића, Боривоја Дробњаковића, Илије Кецмановића и бројних истомишљеника да је Ковчежић „етнографски спис првога реда” и „уједно наш први етнолошки часопис” (РАДОВАНОВИЋ, 1973: 95. УП. МАТИЦКИ, 2015: 505-515).

${ }^{4}$ В. МИЛОШЕВИЋ-ЂОРЂЕВИЋ, 2014. и Даница. Српски народни илустровани календар за годину 2017. у издању Вукове задужбине понела је као програмски поднаслов Вуково из Ковчежсић: Срби сви и свуда (МАТИЦКИ, 2017: 9-13)
} 


\section{Име и садржај Ковчежића}

Грци су свој речник из 1815. године назвали Ковчег језика, према чему је Лукијан Мушицки предлагао Вуку да његов први речник буде именом Ковчег мислене народности србске због описа српских обичаја, како појашњава (ПРЕПИСКА, II, 140). Према Миленку С. Филиповићу - деминутив у наслову Ковчежића за историју, језик и обичаје Срба сва три закона, заиста је „приличио” издању, једновремено је оцењен као „необичан”, „духовит” и „симболичан” (ЕТНОГРАФСКИ СПИСИ 1972: 428).

Још 1836. године Вук пише прва два поглавља Ковчежића, а то је текст Срби сви и свуда, који је био замишљен као уводни текст опису Црне Горе и Црногораца ${ }^{5}$, од чега је сачувана само Бока и изашла је тек у Ковчежићу на петнаестак страна.

„Проскрибовани чланак” І. Срби сви и свуда (1-27) знаковно је обележје првог и уједно последњег Ковчежића и има књижевно, научно, политичко и национално значење. Одељак II. Бока Которска (27-42) био је „подесан увод у етнолошку грађу из Боке Которске" (ЕТНОГРАФСКИ СПИСИ 1972: 430). ${ }^{6}$

Друга два поглавља Ковчежића ауторско-сакупљачки припадају Вуку Поповићу и доносе III. Рисанске обичаје: 1) Женидбе (43-98) и 2) Нарииања за мртвима (98-117) и IV. Српске здравище (118-128). Овај Вуков савременик и сарадник требало је да постане први у низу сарадника на серијској публикацији, али је остао једини. Кад се упореде текстови које је Вук Поповић слао Вуку Караџићу са оним објављеним у Ковчежићу, јасно су видљиве Караџићеве редакторске интервенције и проучавања материјала (ПРЕПИСКА, VII, 5. и ЕТНОГРАФСКИ СПИСИ, 110).

Пети, у Објављенију најављени одељак Критика житија Давидовићева и Карађорђијева, како пише Вук, није могао бити штампан, а требало је да се односи на Житије које је о Давидовићу (иначе, један од 33 потисника против Вуковог Новог завјета на народном језику) писао Јован Хаџић или Милош Светић (1846) и Житије Карађорђа Петровића које је писао сам Димитрије Давидовић (постхумно објављено 1848).

\section{Идеје Ковчежића}

Вук је у предговору Малој простонародюој славено-сербској пјеснариuи (1814) „програмски” истакао да народне песме садрже „битије сербско и

\footnotetext{
${ }^{5}$ Црна Гора и Бока Которска. Иначе, текст на немачком о Црној Гори и Црногорцима само је извод овог необјављеног рукописа за Вуковог живота, и недостају му написи о Боки, као и замишљени уводник. Рукопис је у целини објављиван постхумно, у XX веку.

${ }^{6}$ УП. ПРЕПИСКА, VII, 80.
} 
име”, што у основи представља национални „канон”, којега ће се доследно придржавати до краја свог сакупљачког рада. Реч је о хердеровској концепцији природне поезије: „Овде нема ни едне песне, кою е дух воображеньа, читаньем кньига обогаћен, по правилима Песнотворства измишльавао; него су све оне, кое е сердце у простоти и у невиности безхудожно по природи спевавало" (ПЈЕСНАРИЦА, І, 42; СУВАЈџИЋ 2018: 118-126).

Интересовање за Србе, све и свуда, Вук је показао још у првој Пјеснарици. У њеном Предсловију расправља о ,језгру Сербскога рода” и областима „најчистијега језика” да би у Објављенију на Писменииу, исте године истакао: „да је језик код свакога народа перви знак, који име народа садержава, и да се међу друге народе не помеша, и не изгуби, чува" (ПИСМЕНИЦА, 238). Припремљен сопственим усменим образовањем, познавањем терена и домаћих и књижевних и филолошких прилика, интензивним дружењем са Копитаром, непрестаном писаном и усменом комуникацијом са људима из свих слојева друштва, напорним учењем, Вук је био у току владајућих критичких праваца онога времена (МИЛОШЕВИЋ-ЂОРЪЕВИЋ, 2015: 518-519).

Године 1836. у предговору првим Пословицама Вук даје дијалектолошке белешке о дубровачком, бококоторском, црногорском језику. Бива нападан да користи „бокески језик”, на шта Вук одговара: „међу Бокезима ако се нађе што љепше и правилније, него што се говори амо по нашим крајевима, ми смо дужни оно узети у општи српски језик не гледајући што је њих само 30.000 душа" (ПОСЛОВИЦЕ, 16-17). У тежњи за савршенством и лепотом он је инстинктивно наишао на прави пут како се ствара књижевни језик, тј. узимајући у обзир све дијалекте и узимајући из њих оно што је најлепше.

Вукова теренска сазнања о широкој распрострањености Срба ван граница Србије његовог доба ${ }^{7}$ (од Дрине до Тимока и од Дунава до Старе планине) видљива су у Ковчежићу - то подразумева његова сазнања о терену Косова и Метохије, Босне и Херцеговине, Зете, Црне Горе, Баната, Бачке, Срема, десног Подунавља, од више Осијека до Сентандреје, Славоније, Хрватске, Турске и Аустријске крајине, Далмације, Адријатическог приморја - од Трста до Бојане, Арнаутске, Маћедоније, околине Дибре (српска села у којима се говори језиком ближим српском него бугарском), код последња три пункта није одредио „међе српског досега”. Он пише 1847. да је „одавно желио проћи по југоисточним крајевима данашње Србије највише ради језика и обичаја народа нашега", што касније и у Ковчежићу напомиње, али и своју бојазан да ће са том жељом отићи са овога света (ЕТНОГРАФСКИ СПИСИ 1972: 31). Његова путовања по југозападним крајевима од 1834. до 1838. године уверила су га да је, осим на уском приморском појасу и острвима, исти језик као у Срба свуда.

Вук се, такође, носио мишљу да изради статистику целог српског народа и етнографску карту, и писао је крајем 1841. свим владикама и адми-

\footnotetext{
${ }^{7}$ УП. СТОЈАНЧЕВИЋ, 2008: 21.
} 
нистраторима епархија, и молио их да му пошаљу податке колико има душа православних Срба, колико парохија и колико свештеника, капелана и ђакона, колико има цркава и манастира и колико калуђера. Одговор је добио само из Темишварске епархије (1842). Касније је то мислио проширити на сва словенска племена. Последњи пут се тога ради обраћао владикама с јесени 1858, али не добивши одговоре, тај је план напустио. ${ }^{8}$

Године 1849. Вук је имао критички сакупљен књижевнонаучни материјал и нагомилано животно искуство, што је условило „поливалентну структуру његовог дела”. Према Нади Милошевић-Ђорђевић (2015: 517, 518) створио је „целину која је имплицитно представљала и својеврсну објективизацију његове основне замисли о народној поезији као духовној спони етнички сродног света". Вук износи демографско-статистичке податке, истиче поделу на штокавско, кајкавско и чакавско наречје, заправо бави се географским простирањем говорних, тј. језичких особености, етнодемографским и конфесионалним приликама, износи „концепцију о српском народу свога времена". 9

Пет милиона душа из Вукових написа односи се на штокавце, он их још на почетку делања, 1814. године одређује као „сви Сербљи, од Адријатическога до Црнога мора, које им драго они вјере били” (ПЈЕСНАРИЦА I, 42). Тек петанестак година после почеле су међу Јужним Словенима да се стварају неке од нација у модерном смислу. Знатан број Хрвата поменуте 1836. није ни употребљавао име Хрват, нити био национално опредељен. Људевит Гај 1836. године у „Илирској Даници” прелази на штокавско наречје. Године 1850. текст „Срби сви и свуда” прештампан је у „Опћем загребачком коледару”. Игњат Брлић из Славонског Брода за своју граматику за Славонце пише да је као Вукова за Србе, тј. за један народ по језику. ${ }^{10}$

И да није Аустрија 1842. године забранила употребу имена Илири, оно се не би могло одржати. Словенци и Срби не би га прихватили. После те забране, код католика штокаваца и код чакаваца и кајкаваца почело се утврђивати име Хрват. Како пише Нада Милошевић-Ђорђевић, тадашњи илирски приговори Вуку што није хтео да прихвати илирско име „незлобиви” су и такав Вуков став је свима јасан - немогуће му је било да се одрекне српске историје, књижевности и традиције, које су очувале „идентитет и интегри-

${ }^{8}$ В. ИВИЋ, 1971. и лит.; ПОПОВИЋ, 1964: 326-328.

${ }^{9}$ В. СТОЈАНЧЕВИЋ, 2008: 21-26.

${ }^{10}$ И још додаје - „да ових пет милиона душа који су двојаке вере, да и двојака слова имају, и где би обе стране сједињене врло много учинити могле, да осамљене свака за се могу мање учинити, да једна другој смета, а општа ствар да од тога страда. Зар у Енглеској, Француској и Немачкој, па чак и у Угарској нема више верских секата, па како пишу. Сви једнако. Сваки задржава за себе своју веру, своје обичаје, али сви, сви без разлике, пишу једним језиком, једном азбуком и једним правописом. Само ми, који нисмо ни под једном владом и управом, ми хоћемо у овоме друкчије да радимо. И ко притом губи. Ја мислим pars minor.” УП. ПРЕПИСКА, V, 79-80. 
тет српског народа" (МИЛОШЕВИЋ-ЂОРЂЕВИЋ 2015: 522). Он, притом, своја дела штампа у штампарији јерменског манастира бенедиктинске провенијенције, под управом цензора Копитара, Словенца, продаје старе српске књиге, србуље, и на један начин их спасава, али се ни на тренутак не одриче српског средњовековља нити расправља с њим. ${ }^{11}$

Љубомир Стојановић почетком прошлога века запажа и верује „да су Брлић и Гај били Вукова темперамента и плодности”, па да су, како он пише „засули хрватску литературу ћирилским списима о хрватском народу и о историји, као Вук српску, успели би, јер би их у борби подржали ако не савременици (као што нису ни Вука), а оно доцнији патриоти и књижевници као Штросмајер, Рачки, Јагић и многи други". Такође, верује да би се избегла силна међусобна трвења, која ће касније наступити, тј. дошло би до „духовног уједињења пре политичког”, и све књиге нашле би пут до свих кућа без разлике да ли их је написао Србин или Хрват (СТОЈАНОВИЋ 1987: 688). Говорили бисмо нашим језиком или „по нашки”, и разумели бисмо се. ${ }^{12}$

Кад је изашла Шафарикова Историја словенских књижевности, Вук је писао поменутом Брлићу да је захвалан Шафарику што и Славонце и Далматинце и Рваћане узима по правди међу Србе као и Бошњаке и Црногорце. Шафарик је по доласку у Нови Сад, међу Србе донео европски дух и словенско братство. Повезао се са тадашњом српском интелигенијом, покренуо многа културна питања и успоставио свесловенске везе. Потпуном историјом књижевности Срба сматрао је само ону која би обухватила и књижевне плодове „свих грана тог племена” - самих Срба, Босанаца, Далматинаца, затим Хрвата-граничара и Славонаца. Једна од претпоставки је да је Шафарик тротомну историју српске, хрватске и словеначке књижевности, као део исцрпније историје словенских књижевности, завршио управо $1836 .{ }^{13}$

Како запажа Бошко Сувајџић, оно што је за Доситеја било језичка целина „од Црне Горе до Смедерева и Баната” код Вука се прелило у духовну целину. Доситејев европски круг је био шири захваљујући таласима просветитељства и идејама протестантизма, али се са Вуковим преклапао кад је реч о Лајпцигу, као центру издавања словенских књига и Бечу, као епицентру српске књиге у XVIII и XIX веку, где је у том периоду објављено 1150 веома значајних српских књига. „Све што су чинили Доситеј и Вук на пољу књижевности, намењивали су Србима свима и свуда" (СУВАЈЏИЋ 2018: 127-128).

\footnotetext{
${ }^{11}$ Вид. и СКАКИЋ, 1998: 85-87; АЛЕКСИЋ, 2012: 335-345; уп. МИТИЋ, 2019: 21-29.

${ }^{12}$ Караџићева путовања по југозападу Балкана од 1834. до 1838. године подразумевају његов пут зближавања са хрватском културном средином. Он се, говорећи о једном језику, позива на стваралаштво хрватских писаца Иванишевића, Рељковића, Канижлића, Кнежевића итд., као и на тамошње тужбалице „на народну”.
}

${ }^{13}$ УП. ШАФАРИК 2004. 
Бошко Сувајџић истиче да су средином XIX века и српска национална поезија, и филологија, и религија, и морал, и право, и социологија били утемељени „на Вуковом програму националне културе”. Даље додаје да се ни код једног словенског народа нису стекли тако повољни услови за практично прихватање Хердерових идеја као код нас. „Вук Караџић је то одмах осетио својом изванредном интуицијом, увиђајући какав значај могу имати Хердерове мисли за брзо самостално развијање српске књижевности као оригиналне националне књижевности у оквиру осталих словенских књижевности, и европске књижевности у целини" (СУВАЈџИЋ 2018: 125). Узроци српских и хрватских несугласица налазе се, како закључује Нада Милошевић-Ђорђевић, „у хронолошком раскораку историјског развитка, у времену формирања националне свести код једног и другог народа" (МИЛОШЕВИЋ-ЂОРЂЕВИЋ 2015: 522).

Ми бисмо данас рекли да нема нације без територије, језика и вероисповести, за Вука су те три светиње биле „закон, језик и обичаји”, и како истиче етнограф Миљана Радовановић, Ковчежић је замишљен као „гласило којим се Вук борио за заштиту и очување ових светиња, а преко њих и за саму етничку, народносну компактност и самоодржање" (РАДОВАНОВИЋ 1973: 95). На „закон”, ипак, већ Вук гледа као на „три светиње”, а код етничких особености предност даје ,језику” у односу на „обичајност”.

Ковчежић носи породичне обичаје из Рисна скопчане са свадбом, сахраном и напијањем и наздрављањем „у име”. Српске здравище јесу грађа коју је за Ковчежић добио од Вука Поповића, такође, њих седам бројем Вук касније распоређује по рукописима уз свадбене обичаје и обичаје о крсном имену, пре свега. Грађа је потпуно нова у Вуковом истраживачком корпусу и допуњује претходећи корпус у сваком погледу - указује на разноврсност обичајности и етнолошку грађу допуњује народним стваралаштвом.

Вук као етнограф и етнолог, историчар и социолог културе, анализирао је основне институције традиционалног српског друштва - патријархалну сеоску заједницу, традицију, веру, обичаје, књижевни идентитет, систем и механизме турске владавине, узроке настанка устанака, заснивање и функционисање нове власти, улогу бирократије и нових социјалних категорија у новонасталом друштву, у условима обновљене државности Србије. У методолошком погледу у својим истраживањима Вук се служио најчешће посматрањем, интервјуом и личним учествовањем и искуством, али и историјским документима, коришћењем архивске грађе, и компаративном и статистичком методом.

Вуков методолошки поступак је документарност, критичка анализа и акрибија. Вукова знања о етнографији Срба пореклом су из литературе, казивања савременика и из непосредних истраживања. Завичајем Подринац, пребивалац у Срему и пре и после Првог српског устанка, високи чиновник владе у Неготинској крајини и њен изасланик у Видину - упознаје ге- 
ографију, етнографију и историјске догађаје школујући се у Великој школи у Београду, који је био пун људи - староседелаца, дошљака, избеглица из разних крајева Турског царства, али и емиграната из аустријских области, људи разних занимања, говора и обичаја - што Вуку даје широку слику и разноврсност информатора.

Пре двеста година Вук се окреће Европи разорачан у прилике у Србији, али вазда бранећи духовно и језичко пространство Срба свих и свуда. Језик је сматрао старијим и важнијим чиниоцем идентитета од етничке и конфесионалне припадности. Иако често проказан и као нови зидар „вавилонске куле”, он је вазда зидар само српске куле и гласник језика нешег насушног, јер „народ не деле реке и брда него језици”. Својим прегалаштвом чувао је и сачувао од заборава како смо као нација постајали и постојали, опстајали и опстојали на овом трусном терену - како смо се рађали и умирали, лечили и певали, селили, туговали и веселили, молили и веровали.

\section{Цитирана литература}

АЛЕКСИЋ, Слађана. „Вуков допринос проучавању књижевности у устаничкој Србији", у: Митолошки зборник, 27. Рача: Центар за митолошке студије Србије, 2012, 335-345.

ИВАНИЋ, Душан. „Вук о српском језику и књижевности или Срби сви и свуда”, у: Вук Стефановић Караџић, Срби сви и свуда: о књижевности и језику (предговори, критике, полемике, чланци, писма). Андрићград: Анрићев институт, 2014, 11-45.

ИВИЋ, Павле. Српски народ и његов језик. Београд: СКЗ, 1971.

МАТИЦКИ, Миодраг. „Вуков забавник Данииа као модел националног периодика", у: Вук Стефановић Караиић (1787-1864 - 2014). Београд: САНУ, 2015, 505-515.

МАТИЦКИ, Миодраг. „Србима свима и свуда”, у: Данииа. Српски народни илустровани календар за годину 2017, XXIV година. Београд: Вукова задужбина, 2017, 9-13.

МИЛОШЕВИЋ-ЂОРЂЕВИЋ, Нада. „Ковчежић Вука Караџића”, у: Вук Стефановић Караиић, Ковчежић за историју, језик и обичаје Срба сва три закона, фототипско издање. Београд: Вукова задужбина, 2014, 155-164.

МИЛОШЕВИЋ-ЂОРЂЕВИЋ, Нада. „Вуков Ковчежић и око њега. 'Срби сви и свуда"”, у: Вук Стефановић Караиић (1787 - 1864 - 2014). Београд: САНУ, 2015, 517-524.

МИТИЋ, Кристина. „Српска средњовјековна прошлост у Вуковом првом рјечнику", у: Савремени токовиу научи о језику и књижевности. Тематски зборник радова, књ. 2. Наука и савремени универзитет 8. Ниш: Филозофски факултет, 2019, 21-29. 
ПОПОВИЋ, Миодраг. Вук Стефановић Карауић. Београд: Нолит, 1964.

РАДОВАНОВИЋ, Миљана. Вук Караџић, етнограф и фолклорист. Београд: САНУ, 1973.

СКАКИЋ, Мирко. Вук Карауић у свом и данашњем времену или уочавања са временске дистание. Београд: НБ „Вук Караџић”, 1998.

СТОЈАНОВИЋ, Љубомир. Живот и рад Вука Стефановића Караиића. Београд: БИГЗ, 1987.

СТОЈАНЧЕВИЋ, Владимир. „Вуков спис Срби сви и свуда у историјској ретроспективи", у: Друштвена и политичка мисао Вука Каращића. Београд: Завод за уџбенике, 2008, 21-26.

СУВАЈџИЋ, Бошко. Къига о Вуку. Београд: Албатрос плус, 2018.

ШАФАРИК, Павел Јозеф. Историја српске књижевности. Београд: Завод за уџбенике и наставна средства, Вукова задужбина, Матица српска, 2004.

\section{Извори}

ЕТНОГРАФСКИ СПИСИ. Вук Стефановић Караџић, Ковчежић за историју, језик и обичаје Срба сва три закона, Београд: Просвета, 1972, 31-145, 427-434.

ПЈЕСНАРИЦА, І. Вук Стефановић Караџић, Мала простонародња славеносербска пјеснарииа (1814), Београд: Просвета, 1965, 31-129.

ПОСЛОВИЦЕ. Вук Стефановић Караџић, Српске народне пословиие (1836), Београд: Просвета, 1965.

ПРЕПИСКА, II. Вук Стефановић Караџић, Преписка II (1822-1825), Београд: Просвета, 1988.

ПРЕПИСКА, V. Вук Стефановић Караџић, Преписка V (1833-1836), Београд: Просвета, 1996.

ПРЕПИСКА, VII. Вук Стефановић Караџић, Преписка VII (1843-1847), Београд: Просвета, 1996.

Kristina R. Mitić

\section{A TREASURE CHEST OF VUK'S IDEAS}

The paper presents the path of The Chest for history, language and customs of Serbs of all three religions up to resent days. Several editions of this work have been taken into account, as well as critical reviews of previous researchers of The Chest. These efforts bore fruit so that The Chest did not remain in the shadow and Vuk Stefanović Karadžić's ideas of the time have been preserved and presented.

Keywords: Karadžić, Chest, editions, content, ideas. 